\title{
AS POLÍTICAS PÚBLICAS AMBIENTAIS DO NORDESTE BRASILEIRO E AS OPERAÇÕES PRODUTIVAS: UM ESTUDO COMPARATIVO SOBRE SEUS PRINCÍPIOS E INSTRUMENTOS NO ÂMBITO ESTADUAL
}

\section{THE ENVIRONMENTAL PUBLIC POLICY IN NORTHEAST OF BRAZIL AND THE PRODUCTION OPERATIONS: A COMPARATIVE STUDY ON ITS PRINCIPLES AND TOOLS AT THE LEVEL STATE}

Larisse Santos Cabral de Oliveira ${ }^{1}$; Handson Claudio Dias Pimenta ${ }^{2}$; Reidson Pereira Gouvinhas ${ }^{3}$

\author{
${ }^{1}$ Universidade Federal do Rio Grande do Norte - UFRN - Natal - Brasil \\ larisse.cabral@gmail.com \\ ${ }^{2}$ Instituto Federal de Educação, Ciência e Tecnologia do Rio Grande do Norte - IFRN - Natal - \\ Brasil handson.pimenta@ifrn.edu.br \\ ${ }^{3}$ Universidade Federal do Rio Grande do Norte - UFRN - Natal - Brasil \\ reidson@ct.ufrn.br
}

\begin{abstract}
Resumo
Uma forma sistemática do Estado gerenciar os diversos conflitos de interesses econômicos $e$ sociais com a preservação ambiental é através do estabelecimento de políticas públicas. Ou seja, ma política pública ambiental estabelece um conjunto de objetivos, diretrizes e instrumentos que o poder público dispõe para materializar a visão e o cuidado holístico do meio ambiente. Já se observa a existência de políticas públicas ambientais tanto a nível global, nacional, regional (nordeste), como estadual e local. Porém, há uma carência de estudos quanto à efetividade de seus instrumentos e princípios com relação ao seu foco de ação. Assim, o presente estudo tem como objetivo principal de avaliar as políticas ambientais do nordeste brasileiro, praticadas à nível estadual, através de um estudo comparativo sobre os principais princípios e instrumentos utilizados e suas repercussões para as atividades produtivas. Para isso, adotou-se como metodologia estudos descritivo/comparativo, por meio de pesquisa bibliográfica e documental. As análises dos dados foram feitas com uma abordagem qualitativa através de um exame integral do conteúdo do código/política ambiental de cada Estado nordestino, guiado a partir de um checklist. Como resultado, percebeu-se que há uma predominância no uso de instrumentos de comando e controle, como os padrões de emissão e qualidade ambiental. Foi observado ainda que os instrumentos econômicos, quando da sua existência, faziam valer as sanções penais e administrativas ambientais, na forma de multas, impostos e penalidades.
\end{abstract}

Palavras-chave: políticas públicas ambientais; instrumentos de comando e controle; instrumentos econômicos; operações produtivas. 


\section{Introdução}

O meio ambiente tem uma noção "camaleão", com várias facetas e várias formas de se abordar. A abordagem que sua palavra exprime pode representar um objeto de luxo para os países ricos e com recursos naturais escassos; um alarme pelos economistas sobre os limites do crescimento; ou uma utopia contraditória com o mito do crescimento (PRIUER, 2004). Este pensamento só faz ratificar a idéia de que o meio ambiente é tudo, está contido e contem todas as coisas do planeta. Acreditando nessa idéia, confirma-se a importância do que ele significa.

Muito vem sendo discutido ao redor do mundo sobre os problemas ambientais. Algumas vezes soa até clichê, pois discuti-las traz status e bons olhos da sociedade. Com a citação acima, percebe-se que ações feitas em prol do meio ambiente não são proporcionais as discussões; são pontuais, visando apenas suprir as necessidades observadas no presente não são suficientes para garantir o bem estar das gerações futuras, assim como prega o conceito de Desenvolvimento Sustentável, que atende às necessidades do presente sem comprometer a possibilidade de as gerações futuras atenderem a suas próprias necessidades (COMISSÃO MUNDIAL SOBRE MEIO AMBIENTE E DESENVOLVIMENTO, 1991).

No Brasil, a preocupação pelas questões ambientais foram intensificadas a partir da década de 90, quando da realização da ECO-92, encontro que ratifica o cuidado para com a Terra e seus recursos, tema no qual já vinha sendo debatido à nível mundial desde a Conferência de Estocolmo em 1972. Sendo o Estado, em seus diversos níveis, o responsável pela tutela dos bens ambientais, não esquecendo também do papel da sociedade em cuidar do meio ambiente, assim como trata o art.225 da Constituição Federal de 1988, surge a necessidade de elaborar e fazer valer certas diretrizes, princípios, instrumentos e especificações que venham a regular o uso dos recursos ambientais.

Uma forma sistemática de organizar essas variáveis é através de políticas públicas, onde o Estado define uma conduta a ser seguida, tanto por ele, órgão público, como pelo setor privado. Essas Políticas públicas de cunho ambiental podem se apresentar em diferentes contextos e modos de aplicação. Segundo Barbieri (2007), elas podem se classificar em de comando e controle, econômicas e outras. Ainda existem subdivisões entre cada tipo, abrangendo desde o licenciamento e zoneamento ambiental à incentivos e tributações fiscais em cima de uma determinada variável ambiental (por exemplo, a poluição). Desta forma, se percebe a grandiosidade que este instrumento pode ter caso usado de forma sistemática e planejada.

Já se observa a existência de políticas públicas ambientais tanto a nível global, nacional, regional (nordeste), como estadual e local. Porém, há uma carência de estudos quanto à efetividade de seus instrumentos e princípios com relação ao seu foco de ação. 
Essas PPA's podem se apresentar em diferentes contextos e modos de aplicação. Percebe-se assim, a grandiosidade que este instrumento pode ter caso usado de forma sistemática e planejada.

Diante desse contexto das políticas públicas e frente aos conflitos e situações vivenciados no Brasil nos últimos anos, gera-se a seguinte questão-problema em qual contexto estão inseridas as políticas públicas ambientais do nordeste brasileiro? e Como os agentes impactantes, com o foco nas empresas locais do Rio Grande do Norte, se relacionam com essa temática?

Nessa conjuntura, o objetivo principal do presente estudo é avaliar as políticas ambientais do nordeste brasileiro, praticadas à nível estadual, através de um estudo comparativo sobre os principais princípios e instrumentos utilizados e suas repercussões para as atividades produtivas. Para tanto, esta pesquisa buscou identificar os instrumentos e princípios da política ambiental estadual dos Estados estudados; comparar princípios, instrumentos e práticas oriundos da política ambiental estadual, com as políticas dos demais Estados nordestinos; e verificar o grau de interação da política com o setor empresarial do Estado do Rio Grande do Norte, através da existência de planos, programas e projetos.

Para isso, adotou-se como metodologias estudos descritivo/comparativo, por meio de pesquisa bibliográfica e documental. As análises dos dados serão feitas com uma abordagem qualitativa. A seguir, será exposto o referencial teórico essencial para a compreensão de alguns termos e conceitos sobre a temática, em seguida a metodologia detalhada para a elaboração do estudo e a disposição.

\section{Políticas públicas ambientais: conceitos, princípios e instrumentos}

Uma "política" é o conjunto de procedimentos que expressam as relações de poder entre os membros de uma sociedade e que se destinam à resolução pacífica de conflitos em torno dos bens públicos, mantendo a ordem de um espaço por meio da definição de padrões de conduta. Por sua vez, "política pública" seria o resultado da própria atividade política na alocação de recursos e na provisão de bens e serviços públicos (LAHERA, 2004).

Barbieri (2007, p. 71) define Política Pública Ambiental (PPA) como o conjunto de objetivos, diretrizes e instrumentos de ação que o poder público dispõe para produzir efeitos desejáveis sobre o meio ambiente. Ainda, D’Isep (2009) destaca que a terminologia PPA em si serve de base para materializar valores que se pretendem realizar, no caso em questão, a visão e o cuidado holístico do meio ambiente, que devem refletir na sua gestão.

Já Lustosa, Cánepa e Young (2003) definem PPA como instruções cujo foco de ação que visam reduzir os impactos negativos da ação antrópica. Como toda política, possui justificativa para a sua existência, fundamentação teórica, metas e instrumentos, e prevê penalidades para aqueles que não cumprem as normas estabelecidas. 
A partir desses dos conceitos expostos, uma política pública ambiental objetiva intervir nas atividades do mercado, influenciando um modo de comportamento dos agentes não só envolvidos no setor, mas também de toda a sociedade. Em reflexo, a razão para sua adoção resulta em provocar menos danos ao meio ambiente, seja disciplinando o uso dos recursos naturais ou controlando a quantidade de poluição ambiental.

A seguir, a fim de melhor entender o conteúdo das PPA's, serão abordadas considerações importantes, como os princípios essenciais à uma PPA, os principais instrumentos e seu tipo de abordagem dentro da política.

\subsection{Princípios de Política Pública Ambiental}

A existência de princípios em uma política é essencial para fundamentar, orientar, e dar subsídio na busca de sentido e alcance das normas (LIMA, 2002). Sendo assim, a partir da sua definição, se pensa nos demais componentes da política, como os instrumentos e as diretrizes. Alguns princípios são universais, podendo ser aplicados à vários temas, já alguns são peculiares a cada temática trabalhada. $\mathrm{Na}$ área do direito ambiental alguns princípios tem sua relevância frente à outros, dentre eles o que possui essa característica mais forte é o princípio do Desenvolvimento Sustentável.

Com base em Milaré (2007), o princípio do Desenvolvimento Sustentável surge a partir da conferência de Estocolmo em 1972, sendo posteriormente oficializado pela Organização das nações Unidas (ONU) no documento "Nosso Futuro Comum", em 1987. Tal princípio prega, em palavras simples, o atendimento às necessidades do presente sem comprometer as necessidades das gerações futuras. Os demais princípios são interligados ao ideal deste. A seguir, serão expostos os principais princípios que devem ser considerados em uma política (pública) ambiental.

O princípio da precaução sugere cuidados antecipados com o desconhecido, com o risco incerto (MILARÉ, 2007). Quando não há uma opinião formada, embasada em critérios científicos, não se deve contar com a incerteza de que, no futuro, surgirão alternativas para reverter o quadro originado pelo dano ambiental. Recomenda-se, então, que as ações pretendidas sejam repensadas ou não executadas, até que se tenha plena convicção da reparação, prevenção ou controle do dano/impacto.

Já o princípio da prevenção, que é semelhante ao princípio da precaução, refere-se a antecipação de algum dano ou impacto já conhecido. Um exemplo que o esclarece é o de conhecer os possíveis impactos que uma atividade pode causar ao meio ambiente. Assim, uma decisão pode ser tomada a fim de evitar que tal impacto aconteça, seja com a suspensão da atividade ou com a promoção de ações preventivas. 
Para o princípio do poluidor-pagador possui grande relevância no direito do ambiente e é bastante utilizado nas políticas ambientais. Se baseia na teoria econômica da internalização das externalidades. Este princípio busca imputar ao poluidor o custo social da poluição por ele gerada, engendrando um mecanismo de responsabilidade por dano ecológico, abrangente dos efeitos da poluição não somente sobre os bens, mas sobre toda a natureza (Milaré, 2007, p. 771). Na legislação ambiental brasileira verifica-se não só a presença deste princípio, mas também a forma de combater as chamadas externalidades por meio de sanções penais e administrativas (Constituição Federal, art. $225, \S 3^{\circ}$ ).

Ainda, o princípio da responsabilidade civil objetiva tem como idéia principal centrada ao fato de o autor do fato causador de um possível dano ser o seu responsável moral e legal, bastando apenas que ele se relacione materialmente com este fato. Isso quer dizer que um impacto causado ao meio ambiente, de origem não natural, deve ter o seu devido responsável para que sejam aplicadas as punições acertadas pelo poder público ou previstas em lei.

Por fim, o princípio da consideração da variável ambiental no processo decisório de políticas de desenvolvimento considera a importância de inserir a variável ambiental em qualquer ação ou decisão que venha a causar um impacto negativo ao meio ambiente. Com relação a impactos positivos, deve-se considerar que deve-se alcançar um grau ótimo de qualidade ambiental. O melhor instrumento que demonstra a aplicação desse princípio é a Avaliação de Impacto Ambiental (AIA).

Outros princípios aqui não detalhados também são usados, porém com menor ênfase. Vale destacar ainda o "da natureza pública da proteção ambiental", "do controle do poluidor pelo Poder Público", "da participação comunitária” e "da cooperação entre os povos” (MILARÉ, 2007).

Após expô-los, pode-se estabelecer aos princípios um papel importante em uma política. Durante a formulação de uma PPA deve-se ter claramente o objetivo a ser alcançado, as partes envolvidas e afetadas direta ou indiretamente quando da sua aplicação. Sendo assim, não há necessidade de utilizá-los em demasia, bem como não existe uma média de uso em uma política. Cada possível tema abordado ou ainda, por exemplo, um dado objetivo de ação vai demandar um certo principio (ou vários).

\subsection{Instrumentos de Política Pública Ambiental}

Além de princípios, uma política pública ambiental é feita de instrumentos. A partir do interesse das nações na temática ambiental, vem se criando uma série de instrumentos a fim de facilitar a tomada de decisão, ou ainda se valer para evitar novos problemas ambientais, bem como para eliminar ou minimizar os existentes (BARBIERI, 2007, p. 71). Em outras palavras, recorre-se ao conceito já mencionado anteriormente: é uma forma de internalizar os custos externos oriundos de um possível dano. 
Pode-se classificá-los de acordo com o seu tipo de abordagem: instrumentos de comando e controle, instrumentos econômicos e acordos voluntários. A seguir no Quadro 1 estão os instrumentos descritos na literatura classificados de acordo com o seu gênero:

\begin{tabular}{|c|c|}
\hline Gênero & Espécies \\
\hline $\begin{array}{l}\text { Comando } \\
\text { e controle }\end{array}$ & $\begin{array}{ll} & \text { Padrão de emissão; } \\
\circ & \text { Padrão de qualidade; } \\
\circ & \text { Padrão de desempenho; } \\
\circ & \text { Padrões tecnológicos; } \\
\circ & \text { Proibições e restrições sobre produção, comercialização e uso de produtos; } \\
\circ & \text { Licenciamento ambiental; } \\
\circ & \text { Zoneamento ambiental; } \\
\circ & \text { Avaliação de impacto ambiental. }\end{array}$ \\
\hline Econômico & $\begin{array}{ll}\circ & \text { Tributação sobre poluição; } \\
\circ & \text { Tributação sobre o uso dos recursos naturais; } \\
\circ & \text { Incentivos fiscais para reduzir emissões e conservar recursos (subsídeos); } \\
\circ & \text { Remuneração pela conservação de serviços ambientais; } \\
\circ & \text { Financiamentos em condiçôes especiais; } \\
\circ & \text { Permissões negociáveis; } \\
\circ & \text { Sistema de depósito-retorno. }\end{array}$ \\
\hline Outros & $\begin{array}{ll}\circ & \text { Educação ambiental; } \\
\circ & \text { Apoio ao desenvolvimento científico e tecnológico; } \\
\circ & \text { Unidades de conservação; } \\
\circ & \text { Informações ao público; } \\
\circ & \text { Acordos voluntários; } \\
\circ & \text { Sistema de gestão ambiental (SGA); } \\
\circ & \text { Marketing ambiental; } \\
\circ & \text { Selos ambientais. }\end{array}$ \\
\hline
\end{tabular}

Fonte: Adaptado de Lustosa, Cánepa, Young (2003); Barbieri (2007).

\subsubsection{Abordagem de comando e controle}

A abordagem de comando e controle é a mais utilizada devido à tentativa de se obter controle imediato do que foi inicialmente um dilema incomum e urgente (THOMAS, 2010). O uso de padrões na política é a base fundamental para as políticas públicas de cunho ambiental. Considerando esse fato, vale subdividir a abordagem de comando e controle em:

Padrões de ambiente (qualidade ambiental), os quais determinam o nível de qualidade, estabelecendo limites de poluição; padrões baseado em desempenho (emissões), que definem o quanto se pode poluir independentemente da tecnologia usada (BARBIERI, 2007) para controlar a qualidade ambiental ou do caráter da fonte de poluição (móvel ou estacionária); e os padrões baseados na tecnologia, os quais estabelecem como se alcançará o controle da poluição de acordo com cada agente poluente. 


\subsubsection{Abordagem de mercado (instrumentos econômicos/fiscais)}

Do ponto de vista econômico, os problemas ocorrem devidos às falhas do mercado. Por sua vez, estas falhas podem ser analisadas por dois pontos de vista: o dos bens públicos e o das externalidades. A qualidade ambiental é um bem público, uma vez que não é exclusivo e nem divisível entre uma pessoa e outra. Tais bens públicos geram falhas no mercado por impedir que os incentivos naturais de mercado alcancem um resultado alocativamente suficiente (THOMAS, 2010, p. 68).

Com relação as externalidades, elas podem ser analisadas como positivas (benefício) ou negativa, vista como a geração de custos à terceiros (THOMAS, 2010). Uma externalidade surge quando as transações econômicas entre dois ou mais agentes econômicos produzem um efeito de melhora ou piora da situação de uma terceira parte não participante da transação, sem permissão ou compensação (MORAES, 2009). De forma esquemática, pode-se visualizar este conceito a seguir no contexto das trocas voluntárias que acontecem no mercado entre consumidor/sociedade e empresa e vice-versa.

Percebe-se que os agentes econômicos, que são os consumidores e as empresas, estão executando trocas o tempo todo através do consumo e da produção. Nesse ciclo necessidades e objetivos são alcançadas, estando desta forma todos satisfeitos. Porém tanto para o consumidor como para a empresa, há geração de externalidades negativas não englobadas em seus custos de consumo ou produção. Desta forma, recai sobre o meio ambiente o custo involuntário dessa relação. Então, para que chegue ao fim a geração dessas externalidades é definido pelos teóricos da área econômica que haja a internalização das externalidades (THOMAS, 2010; MORAES, 2009; LUSTOSA; CÁNEPA; YOUNG, 2003), ou seja, ter no custo final do produto os valores correspondentes aos custos externos.

Sendo assim, os instrumentos econômicos podem ser subdivididos em instrumentos fiscais e de mercado. Os instrumentos fiscais são efetivados através de transferências de recursos entre os agentes privados e o setor público, podendo ainda se classificar em tributos ou subsídio (BARBIERI, 2007).

Para subsídio entende-se como o pagamento ou concessão de redução de impostos, que provê assistência financeira para a redução da poluição ou planos para reduzi-la no futuro (THOMAS, 2010). Na literatura consultada, se menciona três tipos de subsídio: um dedicado para os equipamentos de redução da poluição e outro para o corte na poluição, sendo eles executados por meio de isenções, reduções, diferimento de impostos e de financiamentos em condições especiais; o outro tipo de subsídio seria as compensações financeiras pela limitação do uso da propriedade visando à proteção do o meio ambiente (THOMAS, 2010; BARBIERI, 2007). 
Já os tributos, também denominado como "encargos por poluição", são a cobrança de taxa ao poluidor, conforme a quantidade de poluentes lançada (THOMAS, 2010). Segundo Barbieri (2007), os tributos podem ser classificados de acordo com o seu objeto de aplicação (tributos sobre emissões; sobre a utilização de serviços públicos de coleta e tratamento de efluentes; tributação que incide sobre os preços de produtos que geram poluição; entre outros). Exemplos práticos do uso de tributos ambientais são a instituição do ICMS ecológico, a outorga do uso da água, a cobrança de taxa de recolhimento de esgoto, etc.

Para os instrumentos de mercado, sua efetivação se dá através da relação entre as empresas, no espaço do mercado que é regulado pelo governo (BARBIERI, 2007). Para Thomas (2010, p. 31), tal instrumento estimula práticas de conservação ou estratégias de redução de poluição á base de benefícios às empresas, fazendo uso das forças do mercado de forma que a busca de otimização dos poluidores beneficia o meio ambiente.

Como exemplo de instrumento de mercado tem-se os sistemas de depósito/reembolso, os quais consistem em uma cobrança antecipada, cuja finalidade é cobrir possíveis danos em função da poluição (THOMAS, 2010), valor que é devolvido no caso de ações positivas, por exemplo, o retorno de um produto para o descarte apropriado ou para reciclagem. Algumas empresas já promovem ações desse tipo, porém por uma questão meramente de marketing a fim de aumentar o numero de vendas ao passar uma imagem de "empresa ambientalmente correta".

Outro exemplo de abordagem de mercado seria o sistema de comércio de licenças de poluição. Ele se baseia na lógica da criação de créditos e permissões para poluir. Existe várias formas de aplicar esse tipo de instrumento de mercado, sendo elas criadas através da definição de níveis aceitáveis de um determinado poluente no meio ambiente. Um exemplo global e bastante difundido são os créditos de carbono.

\subsection{A Evolução das Políticas Ambientais no Brasil}

No Brasil, as políticas públicas ambientais têm uma história recente. É somente a partir da década de 1930 que são criadas os primeiros códigos, porém os ganhos ambientais obtidos através das políticas se davam de forma indireta.

Entre as décadas de 1930 e 1970 (antes da Conferência de Estocolmo) predominaram a existência de códigos ambientais, ainda não propriamente uma política ambiental formada. $\mathrm{O}$ caráter desses códigos era setorial e visava ordenar alguns temas que mereciam na época uma atenção maior. Entre os temas estavam o fomento à exploração dos recursos naturais, o desbravamento do território, o saneamento rural, a educação sanitária e os embates entre os interesses econômicos internos e externos, que resultaram nos códigos de águas (1934), florestal (1965) e de caça e pesca (1967) (SOUSA, 2005). 
Entrando no período que marcou as mudanças de comportamento em todo mundo, o Brasil passa a adotar uma postura corretiva após a realização da Conferência de Estocolmo. Porém, os regimes político e econômico da época refletiam diretamente no comportamento do governo frente às questões ambientais e a criação de políticas.

Só a partir da década de 1980 é que se passa a adotar uma abordagem preventiva, tanto que em 1981 é criada a lei marco ambiental brasileira: a Política Nacional do Meio Ambiente (PNMA) (lei $\mathrm{n}^{\mathrm{o}}$ 6.938/1981), criando o Sistema Nacional de Meio Ambiente (SISNAMA) e o Conselho Nacional do Meio Ambiente (CONAMA).

A PNMA estabeleceu os objetivos, princípios, diretrizes, instrumentos, atribuições e instituições da política ambiental nacional. Seu o objetivo principal era a preservação ambiental propícia à vida, visando assegurar, no país, condições para o desenvolvimento sócio-econômico, os interesses da segurança nacional e a proteção da dignidade da vida humana. Dentre os seus instrumentos encontra-se a avaliação de impactos ambientais, o licenciamento e a revisão de atividades efetiva ou potencialmente poluidoras (BRASIL, 1981).

Ao longo da década de 1980, outras legislações foram criadas visando atender problemas específicos como, por exemplo, sobre as medidas de prevenção da poluição industrial, a responsabilidade civil e criminal relacionada com atividades nucleares, o regime especial para exploração e aproveitamento das substâncias minerais, entre outros (BARBIERI, 2007).

Como desfecho da década, há outro grande avanço, contido na constituição federal. Um artigo da Constituição Federal (CF - art. 225) é dedicado exclusivamente ás questões ambientais. A escrita desse artigo foi bastante influenciado pelo Relatório Bruntland (Nosso Futuro Comum), o qual define o conceito de Desenvolvimento Sustentável.

Na década de 1990, o país assume uma conduta integradora, pois passa a agregar em suas políticas o conceito de Desenvolvimento Sustentável. Pode-se dizer também que a ECO-92, o evento ambiental mais importante da década, que ocorreu no Brasil, foi mais um despertar para o país, tanto que o modelo até então executado entrou em crise por não atender nem à nova pauta da política internacional definida na Eco-92, nem às demandas de cidadania e de consciência ambiental que se generalizava (SOUSA, 2005). Isso fez com que se evidenciasse, finalmente, a necessidade de redefinição das opções de política ambiental e do próprio papel do Estado brasileiro.

\section{Procedimentos Metodológicos}

No que diz respeito à classificação da pesquisa, o caráter qualitativo é usado por se objetivar no estudo a análise da interação de certas variáveis, compreendendo-as e classificando-as. Além disso, trata-se de uma pesquisa descritiva por se acreditar que estudos dessa natureza propõem-se investigar o "que é", ou seja, descobrir as características de um fenômeno como tal 
(RICHARDSON, 2009). Quanto ao caráter comparativo, seu uso se justifica por buscar as diferenças e semelhanças entre o conteúdo da política ambiental de cada estado nordestino, analisando assim quais são as contribuições que uma pode fazer a outra política.

\subsection{Levantamento de Dados}

A coleta de informações devido ao grande recorte espacial de uma das etapas desse estudo e a inviabilidade de se fazer um estudo in loco é grande foi consulta a internet, por meio das home pages das secretarias estaduais de meio ambiente ou órgãos de defesa do meio ambiente de cada estado. O período de coleta das informações foi entre os meses de janeiro e fevereiro de 2010

Com relação à análise critica da política ambiental do Rio Grande do Norte foi proposto um estudo de caso, considerando o conteúdo da política ambiental estadual (Lei complementar $\mathrm{n}^{\circ}$ 272/2004). Desta forma, serão avaliados seus princípios, instrumentos e o modo de interação que estes tem com o meio empresarial.

Depois de explicitado o meio de coleta, o instrumento utilizado para obter os dados necessários foi o uso de checklist. Tal escolha foi feita a partir da intenção do levantamento: a partir do conteúdo da política nacional do meio ambiente, conhecer o conteúdo das políticas ambientais de cada estado, as ações do órgão gestor (planos, programas e projetos) e ainda sondar o meio de informação/observação usado. Desta forma, o checklist está dividido em quatro partes, melhor detalhadas a seguir.

a) Informações gerais: perguntas abertas para realizar uma breve caracterização do órgão observado. Perguntas como nome do órgão, gestor responsável, início das atividades foram evidenciadas.

b) Políticas ambientais estaduais: perguntas fechadas, utilizando como respostas "sim/não" e comentários quando necessários. Perguntas à respeito do conteúdo da política ambiental são feitas nessa parte, sondando os instrumentos utilizados, os princípios norteadores da política, e ainda a existência de legislação ambiental específica para alguns temas, como recursos hídricos, mudanças climáticas, resíduos sólidos, etc. Para essa ultima abordagem (legislação ambiental específica), sendo que as repostas são definidas por escala, variando da seguinte forma: Não existe ou não observado; Em formulação; Em votação, Em implantação; Plenamente implementada.

c) Ações do órgão gestor: para essa parte do checklist, objetiva-se perceber o modo de atuação do órgão. Sondagens são feitas quanto o modo de integração do órgão com outros setores do governo, a existência de planos, programas e projetos, e parcerias (público-privadas) e a elaboração de material informativo.

d) Meio de observação: finalizando o checklist, a referida parte busca captar a impressão do pesquisador quanto a disposição das informações no meio de informação, bem como o conteúdo e a 
sua confiabilidade. Verificou-se se as informações do site eram obtidas de forma clara e se as mesmas estavam atualizadas.

\subsection{Análise dos Dados Coletados}

As informações coletadas serão analisadas, ao mesmo tempo, sobre a ótica qualitativa e quantitativa. Para a analise qualitativa será feito o uso das análises documental e de conteúdo, a partir do levantamento obtido pelos checklist e da analise critica da política estadual de meio ambiente do Rio Grande do Norte; para a análise quantitativa, caberá a ela a disposição gráfica dos dados, usando gráfico. Não será aplicado nenhum tratamento estatístico aos dados devido a pequena amostragem (9 Estados), não gerando assim um grau de confiabilidade das correlações.

\section{Caracterização da Área de Estudo}

A região Nordeste ocupa uma área de $1.539 .000 \mathrm{~km}^{2}$, correspondente a $18 \%$ do território brasileiro, e abriga uma população de 51,5 milhões de habitantes, equivalentes a quase 1/3 da população nacional (IBGE, 2007). A seguir pode-se observar no Figura 1 a localização da região nordeste considerando o espaço brasileiro, bem como os Estados que compõem tal região.

Figura 1 - Representação espacial dos Estados nordestinos

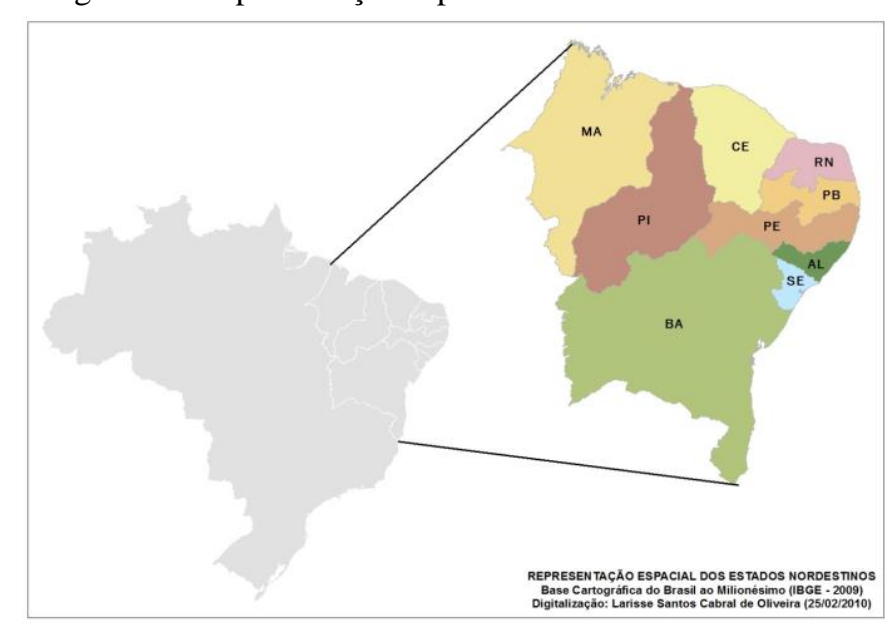

Fonte: Adaptado de IBGE (2009)

Conforme observado acima, os Estados pertencentes da região nordeste são: Alagoas - AL, Bahia - BA, Ceará - CE, Maranhão - MA, Paraíba - PB, Piauí - PI, Pernambuco - PE, Rio Grande do Norte - RN e Sergipe -SE.

A região produz um Produto Interno Bruto per capita de $\mathrm{R} \$ 6.029$, muito abaixo da média nacional (apesar da recente industrialização sofrida pela região a partir da década de 70 promovida pelas políticas de isenção fiscal). Com relação à área ambiental, há um grande investimento público 
na proteção do meio ambiente em relação ao resto do país. O valor de $\mathrm{R} \$ 5,5$ milhões são gastos, $1 / 4$ da quantia gasta em todo o país (IBGE, 2007).

Está sob a influência de 3 biomas: a Mata Atlântica, no litoral, a Caatinga (recentemente definida como bioma, ocupa a maior parte da região); e o Cerrado, abrangendo parte do Maranhão e da Bahia. Possui uma hidrografia relevante para o país, com destaque para o Rio São Francisco. A região enfrenta problemas de gestão de recursos hídricos devido à localização dos habitantes e das fontes de abastecimento: por exemplo, as bacias hidrográficas com grande potencial de abastecimento estão distantes da população.

Em termos geográficos, a região tem caráter heterogêneo, apresentando grande variedade de situações físico-climáticas. Dentre estas, destaca-se a região do semi-árido, que, além da sua extensão de $882.000 \mathrm{~km} 2$ (cerca de $57 \%$ do território nordestino), singulariza-se por ser castigada periodicamente por secas. As secas podem ocorrer sob a forma de diminuição drástica ou de concentração espacial (e/ou temporal) da precipitação pluviométrica anual. Quando ocorre uma grande seca, a produção agrícola se perde, a pecuária é debilitada ou dizimada e as reservas de água de superfície se exaurem. Nessas condições, as camadas mais pobres da população rural tornam-se inteiramente vulneráveis ao fenômeno climático.

Outro fenômeno que agrava o problema das secas é a desertificação. Áreas com maior grau de aridez, devido à alta insolação e a ausência de chuva, perdem o seu potencial produtivo do solo, impossibilitando o desenvolvimento de algum tipo de atividade, seja com a finalidade comercial ou de subsistência.

Por fim, essa região do país merece um olhar atento dos gestores públicos, tanto pelas suas dificuldades enfrentadas, como pelo seu potencial e riqueza.

\subsection{O Rio Grande do Norte}

O Rio Grande do Norte tem uma área de 52.796,791 Km² (IBGE, 2009). É o ponto mais próximo do Brasil com relação ao continente europeu, fazendo limites com os Estados da Paraíba, Ceará e com o oceano atlântico. O Estado tem uma população estimada em 3.137.541 habitantes (IBGE, 2009). Sobre o Índice de Desenvolvimento Humano (IDH) tem o valor de 0,738 (IBGE,2009), estando entre os 10 valores mais baixos do Brasil.

Está sob a influência dos climas tropical úmido na porção litoral do Estado, tropical semiúmido, na porção central agreste, e semi árido quente, com altas taxas de insolação e baixas taxas de pluviosidade durante o ano (TOPGYN, 2009).

Com relação à hidrografia, o Estado possui vários rios vitais para o abastecimento e amenização dos efeitos da seca: os rios Piranhas-assu, Apodi-mossoró e o rio Potengi. Também 
merecem destaque as construções hidráulicas do Estado como a barragem Armando Ribeiro Gonçalves e o Açude Gargalheiras.

Do ponto de vista turístico, há uma intensa exploração do turismo religioso no interior do $\mathrm{RN}$, devido às belas igrejas espalhadas em seu território. O turismo de aventura também é bastante praticado com a apreciação do ambiente natural, como trilhas ecológicas, escaladas, etc.

Ainda, o Estado apresenta uma economia bem diversificada, com a presença das atividades de petróleo, da fruticultura irrigada, extração e beneficiamento de sal e a produção de cerâmica. Também é válido lembrar o setor industrial do Estado, que se concentra próximo a capital, Natal, que consiste principalmente em indústrias têxteis e de bebidas. O Estado ainda conta com uma receita orçamentária anual de $\mathrm{R} \$ 3.146 .751 .618,32$. O Produto Interno Bruto (PIB) do Estado alcançou a cifra de $\mathrm{R} \$ 17,9$ bilhões em 2007 , valor que o elevou a $18^{\circ}$ lugar no ranking da economia dos estados brasileiros e $5^{\circ}$ lugar no Nordeste (IBGE, 2007).

Essas atividades têm importância não só no campo socioeconômico, mas também ambiental. O motivo dessa importância é o fato das atividades ter um elevado potencial de impacto ao meio ambiente. A extração de petróleo, por exemplo, retira a função social da área explorada ao implantar o maquinário para a sua retirada das camadas mais profundas da solo. A cerâmica, além da retirada da lenha para ser usada como fonte energética dos fornos, que por sua vez expelem gases após a queima, também retira a argila do solo.

Por tais motivos, se faz necessária a existência de diretrizes que regulamentem o uso do meio ambiente, bem como a conduta do empreendedor frente as questões ambientais. A seguir, será visto um pouco da análise da política estadual de meio ambiente do Rio Grande do Norte, cabendo os comentários necessários para contextualizá-la a realidade do empreendedor potiguar.

\section{Análise e Discussão dos Resultados}

\subsection{Caracterização das Políticas Ambientais Estaduais do Nordeste Brasileiro}

A fim de organizar a disposição dos resultados, no Anexo a, observam-se os órgãos ambientais responsáveis pela gestão do meio ambiente, seus respectivos anos de fundação, a política ambiental estadual e as legislações ambientais complementares.

Com relação aos órgãos ambientais de cada Estado, com exceção do Maranhão, todos os outros têm um órgão independente da secretaria de meio ambiente. Este Estado é o único a possuir apenas a secretaria de meio ambiente, tendo as ações vinculadas ao meio ambiente administradas e executadas pela própria secretaria, e não por um órgão ambiental específico para tal fim. Ainda mais, os Estados da BA, CE, PB, PE e RN possuem agencias reguladoras e de gestão dos Recursos Hídricos (embora as nomenclaturas variem em cada Estado). 
Esse tipo de organização com órgãos com certa autonomia das secretarias de Estado, mostra a preocupação do poder público estadual em promover uma gestão ambiental mais focada, não descartando a idéia de que é importante a discussão em todas as secretarias do governo da temática ambiental e a inserção de variáveis ligadas à ela na tomada de decisão.

Sobre o ano de criação de cada um desses órgãos ambientais, a maioria data da década de 1970 (exceto o Estado do Ceará e Piauí), momento no qual o planeta despertava para a importância das questões ambientais.

Isso mostra que apesar de tímidas, as mudanças ocorridas naquela época se mostram como um passo significante, ao considerar a necessidade de discutir as questões ambientais assim como já eram discutidas os temas da segurança, educação e saúde, por exemplo. Sendo assim, pode-se observar que o passo seguinte é a criação de normas e diretrizes para efetivar a tutela do meio ambiente por esses órgãos.

Considerando essa efetivação a partir da criação de políticas ambientais estaduais, percebem-se três tipos de comportamentos para os Estados nordestinos, sendo eles: a criação imediata da política estadual ambiental em conjunto com a criação do órgão de defesa do meio ambiente; a criação da política ambiental posteriormente a criação do órgão, com uma diferença de no máximo 10 anos; e um ultimo comportamento seria a criação da política com uma diferença de mais de 2 décadas com relação a criação do órgão ambiental, sendo os Estados que se encaixam nessa situação o Rio Grande do Norte e Sergipe.

Para o primeiro comportamento pode-se creditar maior confiança quanto à preocupação com a gestão ambiental, uma vez que não basta ter um órgão específico para tal ação, também é preciso que existam diretrizes, princípios e instrumentos que norteiem as suas ações. Outros requisitos que se observam para que se efetive a ação do órgão ambiental é a criação de um conselho e do sistema estadual do meio ambiente, formado por técnicos e representantes dos diversos ramos da sociedade, semelhante à estrutura proposta pela PNMA à nível de Brasil.

Para aqueles que se encaixam no ultimo comportamento, com a tardia criação de sua política ambiental, observam-se algumas particularidades quando comparadas as políticas ambientais criadas em tempos anteriores a essas. Por terem sido criadas recentemente, essas políticas têm agregadas ao seu conteúdo maior valor ambiental, com a inserção de novas variáveis e abordagens ambientais. Esse comportamento é evidenciado inclusive na política estadual do Rio Grande do Norte, a qual discorre longamente sobre o licenciamento, a compensação ambiental e também sobre instrumentos econômicos (esses fatos serão evidenciados na análise da Política Estadual de Meio Ambiente do RN, na próxima seção).

Com relação à legislação ambiental complementar de cada Estado observou-se que todos eles tem uma política estadual de recursos hídricos. Este fato pode ser justificado pela grande 
problemática vivida no nordeste como um todo, que além da escassez de água, esta parte do território sofre com a má distribuição espacial das fontes de abastecimento com os centros de consumo, tanto rural como urbano. Pensando nisso, está mais que clara a necessidade de haver um instrumento de gestão que venha a regular captação, uso e distribuição deste bem natural.

Outras políticas que merecem destaque são as de resíduos sólidos, presentes no Ceará, em Pernambuco, em Sergipe e no Rio Grande do Norte (porém, neste último estado está em processo de implantação). Este assunto também é de relevância, uma vez que este é um problema presente, principalmente nos centros urbanos e industrias, cuja produção de resíduos é feita em larga escala e com a possível existência de resíduos perigosos (que podem por em risco a saúde da população e a qualidade ambiental), respectivamente.

É importante também citar a instituição da lei de ICMS ecológico nos Estados do Ceará, Pernambuco e Piauí. No Rio Grande do Norte, inclusive, existe o projeto para a implantação desse instrumento, porém não está, no momento, sendo discutido no governo. Dentre as legislações consultadas na pesquisa, é a única que se utiliza como foco principal de suas ações um instrumento econômico como lei. Esse instrumento vem sendo utilizado em todo o Brasil para estimular conservação da biodiversidade, porém é importante destacar que outros fatores ambientais são considerados, como a gestão de resíduos sólidos e o tratamento de esgotos, variando de acordo com as demandas e definições de cada Estado.

Ainda, vale ressaltar a implantação da política estadual de mudanças climáticas, na Bahia e no Rio Grande do Norte, e a criação recente de outras políticas no Estado do Piauí: as políticas estaduais de reciclagem de materiais (lei $n^{\circ} 5733 / 2008$ ) e de incentivo ao aproveitamento da energia solar (lei no 5936/2009). São temáticas cuja abordagem não foi observada á nível de política estadual nos demais Estados. Além disso, a política estadual de incentivo ao aproveitamento da energia solar é bastante importante à nível de nordeste, onde a o nível de insolação atinge altas taxas, propiciando assim um cenário a favor do aproveitamento desse tipo de energia. Sendo assim, seria um bom eixo temático a ser trabalhado como política nos outros Estados.

\subsection{Caracterização dos princípios, instrumentos e ações oriundas das políticas ambientais estaduais}

Com relação aos princípios e instrumentos, bem como os eixos temáticos abordados pelos planos, programas e projetos de cada política ambiental estadual, pode-se visualizar no Anexo B a organização dessas informações. De antemão, antecipa-se que as análises feitas a seguir não incluem o estado de Pernambuco, uma vez que não foi observada a existência de política ambiental estadual (observou-se apenas a existência de legislação ambiental setorial, com enfoque em alguns objetos de política, como exposto no Anexo B). 
Analisando esses dados, percebe-se que com relação aos princípios norteadores das políticas há a presença massiva de dois deles: o da prevenção e precaução e o do controle do poluidor pelo poder público. Não desconsiderando os demais, mas esses dois princípios são importantes, pois o primeiro propõe em sua aplicação medidas preventivas de controle e o segunda atesta a responsabilidade do Estado em aplicar as sanções cabíveis ao poluidor.

Merece destaque ainda os princípios do desenvolvimento sustentável e o do poluidor pagador. Para o primeiro sua importância quanto uma questão de conceito difundida e em todo mundo, que norteia não só políticas públicas, mas também as políticas ambientais das empresas com nível de consciência elevado; para o segundo, sua importância está na orientação que ele dá aos instrumentos econômicos. Uma política ser orientada pelo principio do poluidor pagador é sinal de que instrumentos econômicos serão usados.

Por outro lado, o princípio da participação comunitária foi usado em menos da metade dos Estados (BA, CE, MA e PI). O estranhamento pela pouca relevância desse princípio nos estados estudados é o de se considerar importante a presença da sociedade civil, seja ela de forma organizada ou não, no processo de decisões das políticas. A participação desse setor deve acontecer em todas as etapas (formulação, implantação, etc), uma vez que ela será atingida com os reflexos diretos ou indiretos (dependendo do caráter da pesquisa). Tem o seu valor também a comunidade empresarial, por estar diretamente envolvida com as atividades de potencial poluidor, e a acadêmica, por dar contribuições às discussões com o enfoque técnicos das temáticas.

Agora, sobre aos instrumentos usados nas políticas, percebeu-se a predominância da abordagem de comando e controle, principalmente os padrões de qualidade ambiental e de emissões, observando o seu uso em todos os Estados.

Em se tratando do uso dos instrumentos de comando e controle, tem-se em mente que o seu uso é fundamental para ações de regulamentação, porém se discutiu no referencial teórico a eficiência de sua aplicação frente aos instrumentos econômicos, pouco usados à nível de política ambiental estadual. Apenas a política ambiental da Bahia contem um capítulo especial para tratar desse tipo de instrumento. Merece destaque também a do Rio Grande do Norte, cujos detalhes serão expostos nas próximas seções.

De certo, uma inferência pode ser feita em relação aos instrumentos usados em cada política: quanto mais recente a formulação da política ou a sua atualização, mais incrementada em princípios e instrumentos ela fica. Alias, os instrumentos adicionados a ela possuem a abordagem de mercado, como tributos, incentivos e subsídios.

Esse fato é tão verdade que essa comparação entre políticas de criação recente e de criação anterior vão além dessa característica. A seguir, pode-se observar algumas delas no Quadro 2: 
Quadro 2 - comparação das políticas ambientais estaduais com relação ao tempo de criação.

\begin{tabular}{|c|c|}
\hline $\begin{array}{c}\text { Políticas Ambientais Criadas Recentemente } \\
\text { (Última Década) }\end{array}$ & Políticas Ambientais Antigas \\
\hline $\begin{array}{l}\text { Maior detalhamento nos conceitos das variáveis } \\
\text { ambiental }\end{array}$ & Conceituação mínima das variáveis ambientais \\
\hline $\begin{array}{l}\text { Maior quantidade de itens relacionados ao meio } \\
\text { ambiente mencionados }\end{array}$ & $\begin{array}{l}\text { Presença de poucos itens ligados ao meio } \\
\text { ambiente }\end{array}$ \\
\hline Norteada por um maior número de princípios & Uso de poucos princípios \\
\hline $\begin{array}{l}\text { Baseado em instrumentos de comando e } \\
\text { controle, com o reforço dos instrumentos } \\
\text { econômicos }\end{array}$ & Foco nos instrumentos de comando e controle \\
\hline $\begin{array}{l}\text { Maior possibilidade de trabalhar o conteúdo da } \\
\text { política em planos, programas e projetos }\end{array}$ & $\begin{array}{l}\text { Poucas opções de trabalho em planos, } \\
\text { programas e projetos a partir das diretrizes da } \\
\text { política }\end{array}$ \\
\hline
\end{tabular}

Fomte: Os autores (2012)

Com o passar dos anos e do aumento das discussões a respeito da variável ambiental, leva-se a crer que a variável tempo é um fator aliado a construção dessas políticas, uma vez que estão incrementadas de conceitos recentes e mais atentas aos demais instrumentos de política ambiental, além dos de comando e controle.

Um exemplo disso é a comparação entre os extremos temporais das políticas ambientais analisadas no recorte espacial em questão: As políticas estaduais do meio ambiente de Alagoas (lei n 4090/1979) e de Sergipe (lei no 5858/2006).

Primeiramente, o detalhamento dos artigos não é considerável na lei do Estado alagoano, abrindo assim brechas para eventuais contestações na justiça. Depois, deve-se considerar a disposição das diretrizes propostas pelas referidas leis: as informações da política ambiental de Alagoas consistem em objetivos, conceitos, sanções penais e disposições finais, sendo apenas nessa ultima seção mencionada algo sobre padrões de qualidade ambiental e emissão, licenciamento e fiscalização; já na política ambiental do Estado de Sergipe, há um maior detalhamento nos itens contidos nela. Diretrizes gerais são explicitadas, delegando funções para cada órgão ambiental existente na hierarquia do governo. Traz também conceitos, porém em quantidade maior e melhor detalhados. Conta ainda com uma vasta quantidade de princípios e objetivos, refletindo assim também na quantidade de instrumentos utilizados, estes que possuem tanto a abordagem de comando e controle como a econômica.

Por fim, é importante deixar claro que ter uma política ambiental que aborda vários itens não garante a sua eficácia. Além da ação do órgão gestor, é necessária também a existência de planos, programas e projetos que transformem os artigos da lei em ação propriamente dita. 
Com relação a esses planos, programas e projetos (PPP's) no nordeste brasileiro a maioria deles está vinculada a legislação ambiental complementar dos Estados, que por sua vez foram criadas a partir do conteúdo das políticas ambientais.

O eixo temático mais trabalhado não é nenhuma surpresa: é a gestão dos recursos hídricos, com a criação dos comitês de bacia e de planos de gerenciamento dos recursos hídricos. Merece destaque também, pelo contexto em que se encontra o nordeste, as ações ligadas ao combate à desertificação, existindo planos de combate a desertificação e mitigação dos efeitos da seca nos Estados. Porém, o plano é vinculado à uma política de âmbito nacional (PAN-Brasil), executada localmente pelo órgão ambiental de cada Estado.

A educação ambiental também é bastante explorada nos PPP's. O motivo para isso é o fato de mudar a consciência dos atores sociais, usando variadas metodologias, adaptadas à realidade de cada um. Além do mais, seu uso pode ser um meio de atingir os objetivos de PPP's que abordam outros eixos temáticos. Por exemplo, pode se trabalhar a educação ambiental em programas de licenciamento, onde o empreendedor é conscientizado da necessidade de estar legalmente licenciado para executar suas atividades.

\subsection{Estudo de Caso: a Política Estadual do Meio Ambiente do Rio Grande do Norte}

A Política Estadual do Meio Ambiente (PEMA) do Rio Grande do Norte é regulamentada pela lei complementar $n^{\circ} 272 / 2004$. Anteriormente a ela, existiram outras leis que expressavam as diretrizes para a tutela do meio ambiente por parte do poder público estadual. A base de tudo foi a lei ${ }^{\circ}$ 5147/1982, que dispunha sobre a política de controle e preservação do Meio Ambiente. em seguida, em 1996, a lei complementar nº 140 veio a alterá-la e também dando novas providências. Por fim, feito a atual PEMA datada de 2004, que já foi alterada três vezes: uma em 2005 (lei $\mathrm{n}^{\circ}$ 291), outra em 2006 (lei no 336) e por ultimo em 2008 (lei n 380 ).

A PEMA dá orientações gerais e estabelece conceitos legais, como também impõe sanções administrativas ambientais. Ainda, trata da auditoria ambiental, o licenciamento, a compensação, as unidades de conservação e outras providências, norteadas sempre pelos princípios e instrumentos definidos por ela. Tudo isso visa o estabelecimento das condições necessárias para o desenvolvimento sustentável no Estado do Rio Grande do Norte (art. 1).

\subsubsection{Princípios, diretrizes e Instrumentos da PEMA}

A política de meio ambiente do RN é orientada sob os seguintes princípios: Princípio do uso sustentável dos recursos ambientais; Princípio do acesso equitativo aos recursos naturais; Princípio da precaução, prevenção e proteção ambientais; Princípio da informação ambiental; Princípio do usuário e poluidor pagador; e Princípio da reparação ambiental. 
Esses princípios se adéquam aos objetivos propostos pela lei, uma vez que, dentre eles, se procura compatibilizar o desenvolvimento econômico-social com a preservação da qualidade do meio ambiente (art. 3, inciso I), estabelecer critérios e padrões de qualidade ambiental (art. 3, inciso III) e impor ao usuário, poluidor ou degradador a obrigação de manter o equilíbrio ambiental, recuperar ou indenizar os danos causados (art. 3, inciso VII).

Observa-se uma redundância, pois praticamente o que é imposto como principio da política vira um objetivo. Porém pode-se julgar esse caso como necessário a fim de fortalecer o conteúdo da política, evitando assim possíveis "brechas” na interpretação da lei.

Além dos princípios, a lei contem diretrizes contidas no art. 4, as quais algumas serão citadas a seguir: a promoção da incorporação dos aspectos ambientais nos planos, políticas, programas e projetos públicos setoriais; o planejamento e a fiscalização do uso dos recursos ambientais; o controle das atividades efetiva ou potencialmente poluidoras; o acompanhamento do estado da qualidade ambiental; e o incentivo a adoção de mecanismos de auto monitoramento pelos empreendimentos ou atividades com potencial de impacto ambiental.

Essas diretrizes são essenciais na execução das ações a que eles propõem. Por exemplo, a primeira citada pode facilitar e muito a gestão ambiental, uma vez que orienta a inserção da variável ambiental nos planos, programas e projetos setoriais do governo. Outra importante diretriz é a citada no ultimo tópico, pois já institui um instrumento a ser usado pela política, os incentivos.

Então, como elas podem se articular como instrumentos de promoção da sustentabilidade e competitividade empresarial no âmbito estadual? O cumprimento da legislação não pode ser encarado como uma resposta plausível, pois é obrigação do empreendimento cumpri-las. Apesar disso, a partir de seu conteúdo, o setor empresarial pode inovar e nortear suas ações, indo além do que ela propõe. No caso do desconhecimento da existência de programas, planos e projetos, a empresa pode tomar a iniciativa e se dirigir ao órgão ambiental competente e ver como pode participar e agir. Essa questão da atitude é importante, pois atesta o comprometimento da empresa com as questões ambientais, um dos pontos principais quando se busca a sustentabilidade e a conseqüente competitividade.

A PEMA tem uma serie de instrumentos legais citados em seu art. 11, dentre eles merecem destaque os expostos a seguir: Educação ambiental; Zoneamento ambiental; Compensação ambiental; Normas e padrões ambientais; Monitoramento ambiental; Auto monitoramento ambiental; Auditoria ambiental; e Licenças e a avaliação de impacto ambiental.

Percebe-se que a há uma preferência por instrumentos de comando e controle, como é o caso dos padrões ambientais, tanto de qualidade ambiental como de emissão. Os demais instrumentos citados não possuem uma classificação no que se refere a sua abordagem, porém nem por isso eles perdem seu valor. 
É importante mencionar que apesar de não se verificar a abordagem econômica nessa parte específica da lei que fala sobre os instrumentos, eles são encontrados em outros artigos de forma que se faça valer o que é pregado. Por exemplo, o art. 60 desta lei, que trata sobre as punições das infrações administrativas, deixa claro o uso de dois instrumentos econômicos: multas (incisos II e III) e suspensão, restrição e cancelamento de incentivos fiscais, bem como de participação em linhas de financiamento disponibilizadas por estabelecimentos oficiais de crédito ( $\$ 7^{\circ}$, III).

Ao ser restringido na participação de financiamento e incentivos fiscais ou ser submetido a pagar uma multa, o empresário estará gerando além de um custo, também estará causando prejuízos a sua empresa. Por isso se considera mais eficaz esse tipo de instrumento, pois muda diretamente com a conjuntura da empresa.

\subsubsection{Aplicação dos instrumentos}

Dentre os instrumentos citados pela PEMA, será relatada a aplicação de alguns deles no âmbito estadual. São eles: compensação ambiental, subsídios, automonitoramento e auditoria ambiental.

\subsubsection{Compensação ambiental}

Quando um empreendimento tem o potencial de causar um impacto significativo ao meio ambiente, o empreendedor está obrigado, no caso de seu licenciamento, a adotar a compensação ambiental (art. 22). Segundo a própria lei, a compensação ambiental é a contrapartida do empreendedor à sociedade pela utilização dos recursos ambientais e respectivo proveito econômico, sem prejuízo da responsabilização civil e penal por eventual dano ao meio ambiente (art. $5^{\circ}$, inciso VIII). Em linhas simples, a compensação traduz a responsabilidade do usuário do meio ambiente em compensar, de alguma fora, o impacto ambiental que ele causa.

A maneira encontrada pela lei para a compensação está na forma de repasse financeiro para o apoio e manutenção de unidades de conservação (art. 23, inciso I), financiamento de estudos de viabilidade econômica para o uso sustentável dos recursos naturais da unidade afetada (art. 23, $\S 1^{\circ}$, VI), entre outras finalidades que variam de acordo com o tipo de atividade impactante.

A aplicação desse instrumento é mais bem evidenciada no Estado na atividade petrolífera on shore (feita em terra, no continente). Quando enquadrada sobre a forma de licenciamento, a compensação é traduzida em apoio financeiro (no mínimo $0,5 \%$ dos custos totais para a implantação do empreendimento) à ações que promovem a preservação e a conservação (arts. $22 \mathrm{e}$ 23). Um caso interessante é o da Petrobrás, o qual compensa o impacto resultante da extração de petróleo no município de Macau, entre outras ações, com o apoio à Reserva de Desenvolvimento 
Sustentável (RDS) Estadual Ponta do Tubarão, localizada mais precisamente nos distritos de Diogo Lopes e Barreiras.

Dentro da Reserva, a Petrobrás executa programas de cunho socioambiental. A existência do Centro Petrobrás de Desenvolvimento Sustentável (conhecido como RANCHO) oferece um espaço para manifestações artísticas e culturais, reuniões e palestras, cursos, capacitação de pessoal para o apoio às ações de arte-educação, valorização da cultura regional e apoio para o desenvolvimento de atividades econômicas sustentáveis nas comunidades, entre outros objetivos, os quais são norteados pela lei ${ }^{\circ} 8.349$, de 17 de julho de 2003, que regulamenta a criação da RDS.

Outro exemplo da aplicação da compensação no Estado seria a obrigação da reposição florestal quando feito o uso de matéria prima suprimida de vegetação natural (art. 27-A). Pensando na efetivação desse artigo, em 2007 foi criado o programa Selo de Neutralidade em Emissão de Carbono para as empresas potiguares, através da lei $\mathrm{n}^{\circ} 8.994$.

Neste caso, a compensação ocorre a partir da neutralização das emissões diretas e indiretas de carbono provenientes de sua atividade, através do plantio de árvores, incentivando assim a empresa ter algum tipo de responsabilidade ambiental.

\subsubsection{Subsídios}

O mesmo programa citado anteriormente faz uso de instrumentos econômicos do tipo subsídios. Após o cadastramento do empreendedor no programa, ele passa a ter prioridade em linhas de crédito para o investimento em sua empresa no que tange a busca por melhores tecnologias a fim de causa menos emissão de carbono na atmosfera.

Desta forma, os subsídios obtidos pelo empreendedor irão melhorar a qualidade ambiental (do ar, principalmente) e proporcionará à empresa a melhoria contínua de seus processos, uma vez que haverá o emprego de novas tecnologias, mais eficientes e menos poluidoras.

Além disso, o empresário ganha a oportunidade de divulgar a conquista do selo, podendo ainda fazer o uso do marketing ambiental que, como consequiência, transmitirá à sociedade a imagem de empresa ambientalmente correta. Apesar da existência dessas possibilidades de aplicação, não se observou o nível de implantação deste instrumento: está contido na PEMA, porém não há ações oriundas de planos, programas ou projetos.

\subsubsection{Auto monitoramento}

De acordo com o potencial de degradação do empreendimento, a lei obriga que as empresas promovam o auto monitoramento (art. 40), enviando ao órgão competente o relatório ambiental referente ao seu desempenho. 
Mais uma vez, as informações coletadas através desse auto monitoramento poderão virar relatórios ambientais da empresa, estando disponível a sociedade. Assim, ela estará mostrando a ética ambiental, ao mostrar que está dentro dos padrões de qualidade ambiental e de emissão, e a transparência de suas ações. Ainda, o conjunto dessas ações poderão resultar no marketing ambiental, que trará vantagem competitiva à ela. E mais, através de benchmark (ambiental), o empreendedor poderá comparar e registrar, em termos quantitativos o desempenho ambiental nas áreas de impacto ambiental significativo, como, por exemplo, energia, água e resíduos, ou ainda algumas variáveis de impacto socioeconômicos (valorizando neste caso a responsabilidade social corporativa.

Para esse instrumento, devido ao caráter interno das ações (limitadas à relação entre empresa e órgão ambiental fiscalizador), se observou uma tímida aplicação, esta que por sua vez consiste na elaboração e emissão de relatórios trimestrais pela empresa destinado ao IDEMA. Ele os analisa e julga como pertinentes ou não. Em caso de não conformidade, o IDEMA poderá solicitar a empresa a revisão do relatório dentro de um prazo estabelecido. Todo esse procedimento mantém a empresa de acordo com a lei e o não cumprimento pode acarretar prejuízos ao empresário (suspensão da licença de operação, por exemplo).

\subsubsection{Auditoria ambiental}

Semelhante ao auto monitoramento, estão obrigados a executar a auditoria ambiental os empreendimentos de elevado potencial poluidor, ou que apresentam histórico de ocorrência de degradação ambiental (art. 41). A auditoria consiste na avaliação do comportamento de uma empresa, levando-se em consideração a conformidade dela com quesitos ambientais (MACHADO, 2005). Desta forma, a auditoria que a PEMA propõe deve abordar os seguintes itens: os níveis efetivos ou potenciais de poluição; as condições de operação e de manutenção dos equipamentos e sistemas de controle de poluição; medidas a serem tomadas para restaurar o meio ambiente; avaliação de riscos de acidentes; capacitação dos trabalhadores para as funções delegadas; e o atendimento a legislação (art. 43, incisos I, II, III, IV, V e VI).

A lei ainda define que o relatório da auditoria deverá propor as medidas para restaurar o meio ambiente e proteger a saúde humana, identificar as possíveis falhas ou deficiências do sistema e propor soluções que permitam minimizar a probabilidade de exposição de operadores e do público a riscos provenientes de acidentes hipotéticos mais prováveis e de emissões contínuas que possam afetar direta ou indiretamente sua saúde ou segurança (art.43, §1 ${ }^{\circ}$, I, II e III), cabendo ao SISEMA, órgão superior estadual, a definição dos prazos para a implantação das medidas e ações propostas pelo relatório (art.43, $\S 2^{\circ}$ ). Essas auditorias devem ser realizadas por pessoas com capacidade técnica para tal fim, cabendo a responsabilidade de sua execução e resultados à elas, como também 
a empresa submetida à auditoria (art.44). Percebe-se assim que o conteúdo da lei é vago quando trata deste instrumento, pois não existe um documento além da lei que venha a detalhar os itens que deverão conter na auditoria, podendo desta forma ocorrer possíveis problemas quanto a aplicação de alternativas para burlar a PEMA.

Apesar dessas definições e exigências, na prática esse instrumento não está consolidado no Estado, uma vez que pouco se percebe a sua aplicação direta. Apesar disso, vinculado ao licenciamento, algumas atividades tem como documentos exigidos como pré-requisitos na concessão da licença uma auditoria ambiental executada no empreendimento.

\section{Considerações Finais}

As políticas públicas ambientais são um ótimo instrumento de gestão ambiental pública quando elaboradas sobre os princípios certos, contendo as diretrizes e instrumentos em harmonia com o cenário de sua aplicação. A certeza de sucesso em sua aplicação é quase garantida, faltando apenas determinar os planos, programas e projetos que ela irá originar.

Depois de um tardio despertar para as questões ambientais, o Brasil desenvolveu sua política nacional do meio ambiente, dando espaço para que os Estados criassem também as suas no âmbito estadual. A nível de nordeste, a legislação ambiental, traduzida neste contexto na política estadual de recursos hídricos de cada Estado, atenta para a principal problemática da região: a gestão dos recursos hídricos. Ainda, como esperado, as políticas ambientais estaduais constam em sua maioria de instrumentos de comando e controle, mais precisamente os padrões de qualidade ambiental e de emissão. Cabe aos instrumentos econômicos, quando eles existem, fazer valer as sanções penais e administrativas ambientais, na forma de multas, impostos e penalidades.

Apesar disso, alguns dos Estados analisados estão a frente quanto a criação de políticas

ambientais setoriais. É o caso do Piauí, com suas políticas estaduais de reciclagem de materiais e de incentivo ao uso da energia solar, e do Ceará, Pernambuco e mais uma vez, Piauí, com a instituição da lei do ICMS ecológico.

Com relação ao Estado potiguar, o Rio Grande do Norte possui uma política ambiental sólida, seus princípios, diretrizes e instrumentos estão bem dispostos na lei. O uso de instrumentos de comando e controle estão combinados com os econômicos (cobrança de tributos, principalmente, e subsídios), aumentando assim a eficiência de suas aplicações e, conseqüentemente, dos objetivos da política. Os programas oriundos da política podem atender as demandas tanto do governo como do setor empresarial. Ao instituir um programa, o gestor público tem a ferramenta na mão, a de executar a idéia disposta na política e de obter melhor desempenho das empresas no meio econômico, uma vez que a variável ambiental se torna vantagem competitiva no mercado. 
Em contrapartida, o empresário cumpre a lei, e sai ganhando com isso. Os ganhos podem ser físicos, com o incremento de novas tecnologias em seu empreendimento por meio de incentivos e facilidades nas linhas de crédito, bem como ganhos inatingíveis (como reputação e reconhecimento). Desta forma, resta então aos demais atores sociais (sociedade, governo e empresas) a fazer valer o que está escrito.

Embora tais resultados tenham sido alcançados, é importante lembrar que a maioria deles foi obtida através de meio eletrônico, ou seja, os sites dos órgãos ambientais estaduais. Talvez por esse motivo o estudo tenha enfrentado limitações de informações, ao acatar o conteúdo de cada homepage como todas as informações disponíveis sobre a temática.

Sendo assim, se sugere a consideração de um maior espaço de tempo para o levantamento das informações necessárias, fazendo o uso de questionários direcionados aos órgãos ambientais. Desta forma, as barreiras impostas pela distância entre o pesquisador e o objeto a ser estudo são diminuídas e as informações são obtidas de forma completa e atualizadas.

Por fim, fica a sugestão para estudos futuros, como ampliar o recorte espacial e elaborar um estudo comparativo entre todas as políticas estaduais de meio ambiente encontradas no Brasil. Assim, poderá se perceber avanços, retrocessos, enfim, diferenças e semelhanças entre os estados e regiões brasileiras.

\begin{abstract}
The establishment of public policy is a governmental systematic way to manage the wide clash of economic and social interest with environment. In the other words, an environmental public policy rules a set of objectives, goals, guidelines and tools which can be used by government to consolidate the view and holistic care of environment. We can see environmental public policy as much on global and national level as state and local. However, there is a lack of studies related to the effectiveness of its guidelines and tools. Thus, this study aims to analyse the environmental policies from state of Brazilian northeast through the comparative study about the main guidelines and tools that have been used and the repercussion on production activities. According to this, the descriptive and comparison studies were used. The data analysis was took place with a quantitative approach through the checklist application on the environmental law (main public policy on environmental public management) of each state, as well as a specific case study of Rio Grande do Norte state environmental policy. As a result, it was found predominance in command and control' instruments usage, such as environmental quality and emissions standards. It was noted that economic instruments, in their existence, they were used to enforce the criminal and administrative penalties in the form of fines, taxes and penalties.
\end{abstract}

Key-words: environmental public policies; command and control tools; economic tool; production operation.

\title{
Referências
}

BARBIERI, José Carlos. Gestão ambiental empresarial. São Paulo: Saraiva, 2007.

BRASIL. Lei n⿳ 6.938/1981 - Dispõe sobre a Política Nacional de Meio Ambiente e dá outras providências. Brasília. 1981. 
D’ISEP, Clarissa Ferreira Macedo (Org.). Políticas Públicas Ambientais: estudos em homenagem ao professor Michel Prieur. São Paulo: Revista dos Tribunais, 2009.

IBGE - Instituto Brasileiro de Geografia e Estatística. Indicadores de Desenvolvimento Sustentável. Sistema IBGE de Recuperação Automática (SIDRA). Brasilia, $2007 . \quad$ Disponível em: <http://www.sidra.ibge.gov.br/bda/pesquisas/ids/default.asp?o=10\&i=P>. Acesso em: 30 jan. 2010.

LAHERA, P. Eugenio. Política y políticas públicas. CEPAL: Santiago, 2004. (Serie Políticas Sociais, nº 95).

LIMA, George Marmelstein. As funções dos princípios constitucionais. Jus Navigandi, Teresina, ano 6, n. 54, fev. 2002. Disponível em: 〈http://jus2.uol.com.br/doutrina/texto.asp?id=2624>. Acesso em: 07 fev. 2010.

LUSTOSA, Maria Cecília; CÁNEPA, Eugenio Miguel; YOUNG, Carlos Eduardo Frickmann. Política Ambiental. In: MAY, Peter H.; LUSTOSA, Maria Cecília; VINHA, Valéria da (Org.). Economia do Meio Ambiente. Rio de Janeiro: Elsevier, 2003.

MILARÉ, Edis. Direito do ambiente. São Paulo: Revista dos Tribunais, 2007.

MORAES, Orozimbo José de. Economia ambiental: instrumentos econômicos para o desenvolvimento sustentável. São Paulo: Centauro, 2009.

PRIEUR, Michel. Droit de l'environment. Paris: Dalloz, 2004.

SOUSA, Ana Cristina Augusto de. A evolução da política ambiental no Brasil do sec. XX. In: Revista de Ciências Políticas. no 26, nov. - dez. 2005. Rio de Janeiro. 2005.

THOMAS, Janet M. Economia ambiental: fundamentos, políticas e aplicações. São Paulo: Cengage Learning, 2010.

TOPGYN. Clima Rio Grande do Norte (homepage). $2009 . \quad$ Disponível em: <http://www.topgyn.com.br/conso01/rio_grande_do_norte/index.php>. Acesso em: 08 fev. 2010.

\section{Dados dos autores:}

\section{Nome completo: Larisse Santos Cabral de Oliveira}

Filiação institucional: Universidade Federal do Rio Grande do Norte.

Departamento: Dept. Engenharia Civil. Laboratório de Recursos Hidricos e Saneamento Ambiental.

Função ou cargo ocupado: Mestranda do Programa de Pós-graduação em Engenharia Sanitária e Ambiental.

Endereço: Rua Presidente Quaresma, Alecrim. Natal-RN. 59031-150

Telefone: 84 3223-7666

Email: larisse.cabral@gmail.com

\section{Nome completo: Handson Claudio Dias Pimenta}

Filiação institucional: Instituto Federal de Educação, Ciência e Tecnologia do Rio Grande do Norte Departamento: Dept. Recursos Naturais. Núcleo de Estudos em Sustentabilidade Empresarial.

Função ou cargo ocupado: Professor / Pesquisador

Endereço: Rua das Hortencias, 395, Mirassol. Natal-RN. 59078-140. 
Telefone: 84-91347074

Email:handson.pimenta@ifrn.edu.br

Nome completo: Reidson Pereira Gouvinhas

Filiação institucional: Universidade Federal do Rio Grande do Norte

Departamento: Dept. Engenharia de Produção

Função ou cargo ocupado: Professor / Pesquisador

Endereço: Rua Des. José Gomes da Costa, 1886, Apto. 2102, Capim Macio. Natal-RN. 59082-140.

Telefone: 84-91347074

Email: reidson@ct.ufrn.br

Enviado em: 05/05/2012

Aprovado em: 13/07/2012 
ANEXO A - Informações gerais sobre os órgãos ambientais e a legislação ambiental estadual.

\begin{tabular}{|c|c|c|c|c|}
\hline Estado & Nome do Órgão Ambiental & $\begin{array}{c}\text { Ano de } \\
\text { Fundação }\end{array}$ & $\begin{array}{l}\text { Política Ambiental } \\
\text { Estadual }\end{array}$ & $\begin{array}{l}\text { Legislação Ambiental } \\
\text { Complementar }\end{array}$ \\
\hline Alagoas & Instituto de Meio Ambiente (IMA) & 1975 & $\begin{array}{l}\text { Não existe uma política ambiental estadual } \\
\text { propriamente dita, mas sim uma lei que dispõe } \\
\text { a proteção do meio ambiente (lei } \mathrm{n}^{\circ} \\
4090 / 1979 \text { ) }\end{array}$ & $\begin{array}{l}\text { Ordenamento do uso do solo (lei } \mathrm{n}^{\circ} \text { 6061/1998); } \\
\left.\text { Política florestal (lei } \mathrm{n}^{\circ} 5854 / 1996\right) ; \\
\text { Política de Recursos Hídricos (lei } \mathrm{n}^{\circ} \text { 5965/1997); } \\
\text { Licenciamento ambiental (lei nº 6787/2006). }\end{array}$ \\
\hline Bahia & Instituto de Meio Ambiente (IMA) & 1973 & $\begin{array}{l}\text { Existe a Política de meio ambiente e de } \\
\left.\text { proteção à biodiversidade (lei } \mathrm{n}^{\circ} 10431 / 2006\right) ; \\
\text { e a política estadual de administração dos } \\
\text { recursos naturais }\left(\mathrm{n}^{\circ} 7799 / 2001\right) \text {. }\end{array}$ & $\begin{array}{l}\text { Política estadual de recursos hídricos (lei no 10432/2006); } \\
\text { Política estadual de mudanças climáticas (já formulada; atualmente, está } \\
\text { em votação na assembléia legislativa). }\end{array}$ \\
\hline Ceará & $\begin{array}{l}\text { Superintendência Estadual do Meio } \\
\text { Ambiente (SEMACE) }\end{array}$ & 1987 & $\begin{array}{l}\text { Política estadual do meio ambiente do Ceará } \\
\left.\text { (lei } n^{\circ} 11.411 / 1987\right)\end{array}$ & $\begin{array}{l}\text { Uso e ocupação do solo (lei no 10147/1977); } \\
\text { Política estadual de recursos hídricos (lei nº 11996/1992); } \\
\text { Auditoria ambiental (lei no 12148/1993); } \\
\text { Inserção de atividades de Educação Ambiental na Constituição Estadual } \\
\text { (lei no 12367/1994); } \\
\text { Política estadual de resíduos sólidos (lei no 13103/2001); } \\
\text { ICMS ecológico (lei no 14023/2007); } \\
\text { Sistema estadual de Unidades de Conservação (lei no 14390/2009). }\end{array}$ \\
\hline Maranhão & $\begin{array}{lllr}\text { Secretaria } & \text { de } & \text { Estado do Meio } \\
\text { Ambiente } & \text { e } & \text { Recursos Naturais } \\
\text { (SEMA) }\end{array}$ & 1979 & $\begin{array}{l}\text { Código de proteção do meio ambiente (lei } \mathrm{n}^{\circ} \\
\text { 5405/1992). }\end{array}$ & $\begin{array}{l}\left.\text { Política pesqueira estadual (lei } \mathrm{n}^{\circ} 8089 / 2004\right) \text {; } \\
\text { Política estadual de recursos hídricos (lei no 8149/2004); } \\
\text { Instituição de parcerias público-provadas (lei no 8437/2006); } \\
\left.\text { Política estadual de saneamento básico (lei n }{ }^{\circ} 8923 / 2009\right) \text {. }\end{array}$ \\
\hline Paraíba & $\begin{array}{l}\text { Superintendência de Administração } \\
\text { do Meio Ambiente (SUDEMA) }\end{array}$ & 1978 & $\begin{array}{l}\text { Política estadual de controle ambiental (lei } \mathrm{n}^{\circ} \\
\text { 4335/1981, que dispõe sobre a prevenção e } \\
\text { controle da poluição ambiental). }\end{array}$ & Política estadual de recursos hídricos (lei nº6308/1996). \\
\hline Pernambuco & $\begin{array}{l}\text { Agência Estadual de } \quad \text { Meio } \\
\text { Ambiente }(\mathrm{CPRH})\end{array}$ & 1976 & $\begin{array}{l}\text { Não há política ambiental estadual ou } \\
\text { similares. O que existe são leis específicas que } \\
\text { regulam alguns objetos do meio ambiente. }\end{array}$ & 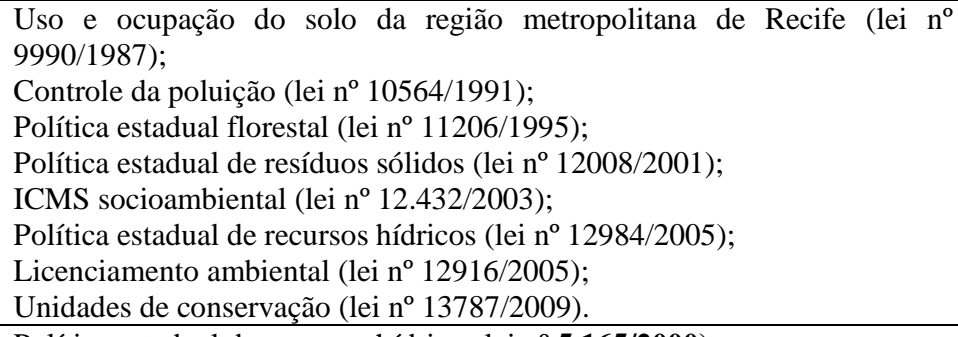 \\
\hline Piauí & $\begin{array}{l}\text { Instituto de Desenvolvimento do } \\
\text { Piauí (IDEPI) }\end{array}$ & $\begin{array}{c}\text { Não } \\
\text { observado }\end{array}$ & $\begin{array}{l}\text { Política de meio ambiente do Piauí (lei } n^{\circ} \\
\text { 4854/1996). }\end{array}$ & $\begin{array}{l}\text { Política estadual de recursos hídricos lei } \mathrm{n}^{\circ} \mathbf{5 . 1 6 5 / 2 0 0 0} \text { ); } \\
\text { ICMS ecológico (lei } \mathrm{n}^{\circ} \text { 5813/2008); } \\
\text { Coleta seletiva em estabelecimentos comerciais (lei } \mathrm{n}^{\circ} \text { 5743/2008); } \\
\text { Política estadual de reciclagem de materiais (lei } \mathrm{n}^{\circ} \text { 5733/2008); } \\
\text { Política Estadual de Incentivo ao Aproveitamento da Energia Solar (lei } \mathrm{n}^{\circ} \\
\text { 5936/2009); }\end{array}$ \\
\hline $\begin{array}{l}\text { Rio Grande Do } \\
\text { Norte }\end{array}$ & $\begin{array}{l}\text { Instituto de Desenvolvimento } \\
\text { Sustentável e Meio Ambiente do } \\
\text { Rio Grande do Norte (IDEMA-RN) }\end{array}$ & 1972 & $\begin{array}{l}\text { Lei complementar } \mathrm{n}^{\circ} \text { 272/2004 (Política } \\
\text { estadual do meio ambiente). }\end{array}$ & $\begin{array}{l}\text { Política estadual de recursos hídricos (lei } \mathrm{n}^{\circ} \text { 6908/1996); } \\
\left.\text { Política florestal do Estado (lei } \mathrm{n}^{\circ} 6769 / 1995\right) \text {; } \\
\text { Plano estadual de gerenciamento costeiro }\left(\text { lei } \mathrm{n}^{\circ} 6950 / 1996\right) \text {; } \\
\left.\text { Zoneamento econômico ecológico (lei } \mathrm{n}^{\circ} 7871 / 2000\right) ;\end{array}$ \\
\hline
\end{tabular}




\begin{tabular}{|c|c|c|c|c|}
\hline & & & & $\begin{array}{l}\text { Política estadual de saneamento básico (lei no }{ }^{\circ} 485 / 2004 \text { ); } \\
\text { Política estadual de resíduos sólidos (inicio da elaboração em 2002; não } \\
\text { observada a fase de implementação em que se encontra); } \\
\text { Política estadual de educação ambiental (em fase de elaboração); } \\
\text { Política estadual de mudanças climáticas (em implementação). }\end{array}$ \\
\hline Sergipe & $\begin{array}{l}\text { Administração Estadual do Meio } \\
\text { Ambiente (ADEMA) }\end{array}$ & 1978 & $\begin{array}{l}\text { Política estadual de meio ambiente (lei } \mathrm{n}^{\circ} \\
5858 / 2006 \text { ). }\end{array}$ & $\begin{array}{l}\text { Uso e ocupação do solo (decreto estaudal 5732/1982); } \\
\text { Penalidades ambientais (resolução no 07/1997); } \\
\text { Política estadual de Recursos hídricos (lei no 3870/1997); } \\
\text { Política estadual de resíduos sólidos (lei n } 5857 / 2006 \text { ). }\end{array}$ \\
\hline
\end{tabular}


ANEXO B - Informações gerais sobre os órgãos ambientais e a legislação ambiental estadual.

\begin{tabular}{|c|c|c|c|c|}
\hline Estado & $\begin{array}{l}\text { Princípios } \\
\text { da Política }\end{array}$ & Instrumentos utilizados na Política & $\begin{array}{l}\text { Eixos Temáticos dos } \\
\text { Planos, Programas } \\
\text { e Projetos } \\
\end{array}$ & $\begin{array}{c}\text { Elaboração de Material } \\
\text { de Apoio }\end{array}$ \\
\hline Alagoas & $\begin{array}{l}\text { Desenvolvimento sustentável; } \\
\text { Prevenção e precaução; } \\
\text { Do poluidor pagador; } \\
\text { Do controle do poluidor pagador. }\end{array}$ & $\begin{array}{l}\text { Padrões de emissão; } \\
\text { Padrões de qualidade; } \\
\text { Licenciamento; } \\
\text { Zoneamento ambiental. }\end{array}$ & $\begin{array}{l}\text { Desertificação; } \\
\text { Recursos hídricos }\end{array}$ & $\begin{array}{l}\text { Folders informativos } \\
\text { sobre os projetos, apenas. }\end{array}$ \\
\hline Bahia & $\begin{array}{l}\text { Desenvolvimento sustentável; } \\
\text { Da natureza pública da proteção ambiental; } \\
\text { Da prevenção e precaução; } \\
\text { Da consideração da variável ambiental no processo } \\
\text { decisório de políticas de desenvolvimento; } \\
\text { Do controle do poluidor pelo poder público; } \\
\text { Do poluidor pagador; } \\
\text { Da função socioambiental da propriedade; } \\
\text { Da participação comunitária. }\end{array}$ & $\begin{array}{l}\text { Automonitoramento; } \\
\text { Educação ambiental; } \\
\text { Padrão de emissão; } \\
\text { Padrão de qualidade ambiental; } \\
\text { Gestão de resíduos sólidos; } \\
\text { Gestão de efluentes líquidos; } \\
\text { Licenciamento; } \\
\text { Unidades de conservação; } \\
\text { Uso e ocupação do solo; } \\
\text { Compensação ambiental; } \\
\text { Concessão de incentivos. }\end{array}$ & $\begin{array}{l}\text { Planejamento ambiental; } \\
\text { Gestão ambiental; } \\
\text { Educação ambiental; } \\
\text { Biodiversidade; } \\
\text { Geoprocessamento; } \\
\text { Mudanças climáticas. }\end{array}$ & $\begin{array}{l}\text { Materiais sobre os mais } \\
\text { variados temas na forma } \\
\text { de: Cartilhas; } \\
\text { Revistas; } \\
\text { Informativos; } \\
\text { Folders; } \\
\text { Cadernos. }\end{array}$ \\
\hline Ceará & $\begin{array}{l}\text { Da natureza pública da proteção ambiental; } \\
\text { Da prevenção e precaução; } \\
\text { Da consideração da variável ambiental no processo } \\
\text { decisório de políticas de desenvolvimento; } \\
\text { Do controle do poluidor pelo poder público; } \\
\text { Do poluidor pagador; } \\
\text { Da função socioambiental da propriedade; } \\
\text { Da participação comunitária. }\end{array}$ & $\begin{array}{l}\text { Educação ambiental; } \\
\text { Padrão de qualidade ambiental; } \\
\text { Gestão de recursos hídricos; } \\
\text { Investimento em ciência e tecnologia; } \\
\text { Padrão de emissão; } \\
\text { Licenciamento; } \\
\text { Uso e ocupação do solo; } \\
\text { Zoneamento econômico ecológico. }\end{array}$ & $\begin{array}{l}\text { Rotulagem ambiental (selo } \\
\text { verde); } \\
\text { Biodiversidade; } \\
\text { Florestas; } \\
\text { Controle ambiental; } \\
\text { Educação ambiental; } \\
\text { Geoprocessamento; } \\
\text { Agenda ambiental da } \\
\text { administração pública (A3P). }\end{array}$ & $\begin{array}{l}\text { Evidenciada apenas uma } \\
\text { publicação: inventário } \\
\text { estadual de resíduos } \\
\text { sólidos industriais. }\end{array}$ \\
\hline Maranhão & $\begin{array}{l}\text { Do meio ambiente ecologicamente equilibrado como } \\
\text { direito fundamental da pessoa humana; } \\
\text { Da natureza pública da proteção ambiental; } \\
\text { Da prevenção e da precaução; } \\
\text { Do controle do poluidor pelo poder público; } \\
\text { Da função socioambiental da propriedade; } \\
\text { Da participação comunitária. }\end{array}$ & $\begin{array}{l}\text { Monitoramento; } \\
\text { Educação ambiental; } \\
\text { Qualidade ambiental; } \\
\text { Biodiversidade; } \\
\text { Recursos hídricos; } \\
\text { Investimentos em ciência e tecnologia; } \\
\text { Padrão de emissão; } \\
\text { Licenciamento; } \\
\text { Unidade de conservação; } \\
\text { Uso e ocupação do solo; } \\
\text { Avaliação de impactos ambientais; } \\
\text { Zoneamento ambiental. }\end{array}$ & $\begin{array}{l}\text { Balneabilidade; } \\
\text { Unidades de conservação; } \\
\text { Biodiversidade (manejo } \\
\text { espécies); } \\
\text { Recursos hídricos); }\end{array}$ & $\begin{array}{l}\text { Não } \\
\text { existente. }\end{array}$ \\
\hline Paraíba & $\begin{array}{l}\text { Do desenvolvimento sustentável; } \\
\text { Da natureza pública da proteção ambiental; } \\
\text { Da prevenção e precaução; } \\
\text { Da consideração da variável ambiental no processo }\end{array}$ & $\begin{array}{l}\text { Licenciamento ambiental; } \\
\text { Fiscalização; } \\
\text { Unidades de conservação; } \\
\text { Audiência pública; }\end{array}$ & $\begin{array}{l}\text { Educação Ambiental; } \\
\text { Poluição ambiental; } \\
\text { Balneabilidade; } \\
\text { Fiscalização; }\end{array}$ & $\begin{array}{ll}\text { Não } & \text { observado/não } \\
\text { existente. } & \end{array}$ \\
\hline
\end{tabular}




\begin{tabular}{|c|c|c|c|c|}
\hline & $\begin{array}{l}\text { decisório de políticas de desenvolvimento; } \\
\text { Do controle do poluidor pelo poder público; } \\
\text { Do poluidor pagador. }\end{array}$ & $\begin{array}{l}\text { Monitoramento; } \\
\text { Gestão de recursos hídricos; } \\
\text { Educação ambiental; } \\
\text { Zoneamento ambiental; } \\
\text { Padrão de qualidade. }\end{array}$ & Controle Ambiental. & \\
\hline Pernambuco & Não observada a existência de política ambiental estadual & $\begin{array}{l}\text { Não observada a existência de política } \\
\text { ambiental estadual }\end{array}$ & $\begin{array}{l}\text { Biodiversidade; } \\
\text { Gestão ambiental compartilhada; } \\
\text { Educação ambiental. }\end{array}$ & $\begin{array}{ll}\text { Não } & \text { observado/não } \\
\text { existente. } & \end{array}$ \\
\hline Piauí & $\begin{array}{l}\text { Da natureza pública da proteção ambiental; } \\
\text { Da consideração da variável ambiental no processo } \\
\text { decisório de políticas de desenvolvimento; } \\
\text { Do controle do poluidor pelo poder público; } \\
\text { Da participação comunitária. }\end{array}$ & $\begin{array}{l}\text { Automonitoramento; } \\
\text { Educação ambiental; } \\
\text { Qualidade ambiental; } \\
\text { Resíduos sólidos; } \\
\text { Gestão de de rescursos hídricos; } \\
\text { Apoio a ciência e tecnologia; } \\
\text { Padrões de emissão; } \\
\text { Licenciamento; } \\
\text { Unidades de conservação; } \\
\text { Uso e ocupação do solo. }\end{array}$ & $\begin{array}{l}\text { Educação ambiental. } \\
\text { Licenciamento; } \\
\text { Coleta Seletiva; } \\
\text { Recursos hídricos; } \\
\text { Energias alternativas. }\end{array}$ & $\begin{array}{ll}\text { Não } & \text { observado/não } \\
\text { existente. }\end{array}$ \\
\hline Rio Grande Do Norte & $\begin{array}{l}\text { Do desenvolvimento sustentável; } \\
\text { Da prevenção e da precaução; } \\
\text { Da consideração da variável ambiental no processo } \\
\text { decisório de políticas de desenvolvimento; } \\
\text { Do controle do poluidor pelo poder público; } \\
\text { Do poluidor pagador. }\end{array}$ & $\begin{array}{l}\text { Automonitoramento; } \\
\text { Educação ambiental; } \\
\text { Qualidade ambiental; } \\
\text { Padrão de emissão; } \\
\text { Licenciamento; } \\
\text { Compensação ambiental; } \\
\text { Auditoria ambiental. }\end{array}$ & $\begin{array}{l}\text { Monitoramento e controle } \\
\text { ambiental; } \\
\text { Desertificação; } \\
\text { Balneabilidade; } \\
\text { Unidade de conservação; } \\
\text { Educação Ambiental; } \\
\text { Licenciamento; } \\
\text { Gestão ambiental compartilhada; } \\
\text { Geoprocessamento. }\end{array}$ & $\begin{array}{l}\text { Anuário estatístico; } \\
\text { Cartilhas; } \\
\text { Inventário de res. sólidos } \\
\text { industriais; } \\
\text { Atlas do desenvolvimento } \\
\text { sustentável. }\end{array}$ \\
\hline Sergipe & $\begin{array}{l}\text { Do desenvolvimento sustentável; } \\
\text { Da natureza pública da proteção ambiental; } \\
\text { Da prevenção e precaução; } \\
\text { Da consideração da variável ambiental no processo } \\
\text { decisório de políticas de desenvolvimento; } \\
\text { Do controle do poluidor pelo poder público; } \\
\text { Do poluidor pagador. }\end{array}$ & $\begin{array}{l}\text { Automonitoramento; } \\
\text { Educação ambiental; } \\
\text { Qualidade ambiental; } \\
\text { Resíduos sólidos; } \\
\text { Incentivo a ciência e tecnologia; } \\
\text { Padrão de emissão; } \\
\text { Licenciamento; } \\
\text { Unidade de conservação; } \\
\text { Uso e ocupação do solo; } \\
\text { Compensação ambiental; } \\
\text { Zoneamento econômico ecológico; } \\
\text { Avaliação ambiental estratégica. }\end{array}$ & $\begin{array}{l}\text { Licenciamento; } \\
\text { Monitoramento; } \\
\text { Qualidade ambiental; } \\
\text { Educação ambiental; } \\
\text { Agenda ambiental na } \\
\text { administração pública (A3P); } \\
\text { Resíduos sólidos; } \\
\text { Recursos hídricos. }\end{array}$ & $\begin{array}{l}\text { Cartilhas com enfoque } \\
\text { sócio-educativo. }\end{array}$ \\
\hline
\end{tabular}

